\title{
Industry-school projects as an aim to foster secondary school students' interest in technology and engineering careers
}

\author{
Robbert Smit $^{1}$ (D) Nicolas Robin ${ }^{1} \cdot$ Christina De Toffol $^{1} \cdot$ Sanja Atanasova ${ }^{1}$
}

Accepted: 4 July 2019 / Published online: 8 July 2019

(C) The Author(s) 2019, corrected publication October 2019

\begin{abstract}
Industry-school partnerships offer authentic learning opportunities and can support the development of students' interest in a STEM career. The expectancy-value model of achievementrelated choice can help to explain how several factors influence career choice. Interest-enjoyment values and attainment values are most important in students' motivation to participate in out-of-school technology and design activities. Our research question is the following: Is there a development in secondary school students' career interests in science-based technology-related professions while participating in industry-school partnerships? We employed a longitudinal, mixed-methods research design. The sample consists of 213 secondary school students from 9 classes and 72 students from 4 classes in 4 neighbouring schools who served as a control group. All of the students filled out a questionnaire before and after the visit. The questionnaire items were based on scales relating to an expectancy-value model. Four groups of students were interviewed with respect to the industry visit experiences. Analyses indicated that attitudes for applying technology became relevant for predicting career interest in a technology profession in the project group after the end of the project. However, career interest did not increase over time. In the qualitative analysis, four topics emerged that elucidated why career interest did not increase. Overall, the results demonstrate that factory visits combined with embedded tasks are one way to overcome fixed ability self-concepts and allow the students to reconsider a career in the technology and engineering industry towards the end of secondary school.
\end{abstract}

Keywords Industry-school project $\cdot$ Science-based technology $\cdot$ Secondary school . Expectancy-value model $\cdot$ Career interest

\section{Introduction}

Industry-school partnerships offer authentic learning opportunities (Watters et al. 2016) and can support the development of interest in a STEM career (Sasson 2018). This is important because multiple research studies register a growing decline of student interest in STEM subjects (Becker 2010; NGSS Lead States 2013; Organisation for Economic

The original version of this article was revised due to a retrospective Open Access order.

Robbert Smit

robbert.smit@phsg.ch

1 University of Teacher Education St. Gallen, St. Gallen, Switzerland 
Co-operation and Development (OECD) 2006b; Xie and Achen 2009). Effects of out-ofschool learning opportunities, such as visits to industry workspaces, museums or science centres, are also found to foster development in science learning, the development of selfefficacy, and even the sense of belonging to a local area (Sasson 2018). Generally, out-ofschool activities have a strong influence on student interest in science over time (Simpkins et al. 2006). For many such events, participants reported that they enjoyed and learned most from hands-on activities (Laine et al. 2017; Levine et al. 2015). Examining student attitudes helps to explain the impact that out-of-school activities can generate. The results show that interest-enjoyment values and attainment values are most important to students' motivation to participate in out-of-school technology and design activities (Masson et al. 2016).

The objective of our industry-school partnership project was twofold. First, the students (grades 7-9) should experience science-based technology in a local factory. The more specific and long-term target was to induce positive attitudes among students towards a career in the technology and engineering industry. In many countries, technology is not yet a prominent feature of science education. The US National Science Education standards, for instance, integrated technology and engineering in 1996, but despite these early efforts, engineering and technology have not received the same level of attention in science curricula, assessments, or the education of new science teachers in comparison to traditional science disciplines (NGSS Lead States 2013). Out-of-school experiences can be a promising way to overcome possible shortcomings of the curriculum.

Our research is embedded within a Swiss-Austrian development project in secondary schools that lasted for two years. According to Archer et al. (2010) students' identities, which are largely formed around the age of 14, are responsible for their career choices in secondary school. Therefore, it is sensible to create projects for that age group, which help students to determine what career possibilities the engineering and technology field has to offer. The expectancy-value model of achievement-related choice demonstrates how several factors influence career choice. The model also explains how constructs and processes such as self-schema, short- and long-term goals, and identity formation change over time in part in response to the accumulation of new experiences and the acquisition of new information (Eccles 2011). Based on this model, we investigate the development in the students' career interests in technology-related professions over the duration of the project.

\section{Theory}

\section{Science-based technology}

The general public as well as teachers consider technology to be an applied science (Jones et al. 2013). However, this view is somewhat incomplete (Jones 2012). In school, teachers and students should develop an understanding of technology and science as two areas that can interact but are also distinct in nature. This means that technology is often an applied science. Sometimes, however, there is no interaction when products are created without a proper understanding of the scientific background (De Vries 2001). For instance, secondary school students could learn to assemble and use a 3D printer in class without having knowledge of the molecular structure of a thermoplastic. Another ambiguity is that technology education is often confounded with the use of computers in schools. Therefore, in this study we apply the term science-based technology as it is defined in the Programme for 
International Student Assessment (PISA) (Fensham 1988; Organisation for Economic Cooperation and Development (OECD) 2006a).

What topics should students come across in science-based technology lessons? Bybee (2000) sees technology as a subject that provides students with opportunities to learn about the processes of design, fundamental concepts of technology and engineering, and the limits and possibilities of technology in society. Jones (2012) somewhat similar to Bybee, describes technology as a medium for allowing people to expand their possibilities and to intervene in the world through the development of products, systems, and environments. This statement includes the discussion of social aspects, values and ethics in the science classroom, which emphasizes the opportunity to make technology more attractive for women in particular. In the US Next Generation Science Standards (NGSS) technology and engineering have played a prominent role. The term 'engineering' is used here in a wide sense to mean any engagement in a systematic practice of design to achieve solutions to particular human problems. For each disciplinary core concept there are connected engineering practices to be found as well. Further notes in the appendixes describe engineering and technology as opportunities for students to deepen their understanding of science by applying their developing scientific knowledge to the solution of practical problems (NGSS Lead States 2013).

In Swiss lower-secondary schools (grades 7-9) the subject of technology has not been a significant part of the curriculum up to now. The new Swiss 'Curriculum 21' describes technology as part of science with respect to being able to talk about the relevance and the sustainability of technological inventions such as genetic engineering, electric engines, or communication technologies. Students should also possess the capability to use and understand everyday tools (hair dryer, loud speaker, LED, etc.), as well as to test and optimize technical devices. The practical implementation of the new Swiss curriculum is still ongoing. Hence, it is reasonable to assume that Swiss science teachers do not put much emphasis on teaching technology in the secondary classroom yet as this was not a topic in earlier curricula. Studies of science teachers' knowledge regarding teaching technology in German-speaking countries do not exist, but research projects, such as that by Goreth et al. (2015), aim to close this gap. Research has shown that the early years of secondary education are crucial in terms of the impact a teacher can have on students' views of science and careers involving science (Regan and DeWitt 2015). Therefore, it is important that Swiss secondary school teachers receive professional training on how to conduct motivating technology lessons in the science classroom.

\section{Attitudes towards science-based technology}

Student attitudes towards science and technology are included in the PISA 2006 definition of scientific literacy (Bybee et al. 2009). These attitudes comprise interest in science and technology, support for scientific inquiry, and responsibility towards resources and environments. Attitudes towards science-based technology are not specifically identified; rather, the term technology appears in the framework as an appendage to the term science. Hence, it is assumed that attitudes towards science and technology are closely related, which is reasonable from a theoretical point of view. However, there are also some discrepancies, as it is said in the framework that science and technology have complementary roles in society (Organisation for Economic Co-operation and Development (OECD) 2006a). It might be concluded that the relationship between science and technology is not yet well defined. 
In investigating the career interests of the students in science-based technology, the present study makes use of the expectancy-value model of Wigfield and Eccles (2002) (see Fig. 1). Their model has successfully been used before in science research (Henriksen et al. 2015; Riegle-Crumb et al. 2011; Wang and Degol 2013). It explains the achievementrelated choices (e.g., career interest) by the value a student attributes to a task and the student's competence beliefs related to that task. These beliefs in turn determine the student's expectation of success. Eccles et al. (1999) demonstrated that both expectation of success and subjective task value ultimately predict career choices. Students' attitudes are assumed to be influenced by socializer's behaviour and beliefs and by the cultural milieu. Gender influences life choices through the relation of the social role identity formation, collective identity and the hierarchy of values associated with the individuals' expectations of success. As an example, young women place more value than young men on the importance of making occupational sacrifices for one's family and on the importance of having a job that allows one to both help others and do something worthwhile for society (Eccles 2009). On the task value side, the model includes utility value, interest and enjoyment, attainment value (importance for identity) and costs of engaging. The last two of these are especially important for understanding the impact of gender roles on the value students attach to subject-related activities in school. The enjoyment of science seems to be primarily framed in terms of the hands-on elements of experiments. Based on a longitudinal study of elementary school students, Archer et al. (2010) determined that younger students enjoy a form of school science framed in terms of "doing science" rather than being or becoming scientists. In their interviews many students reported that they also practised science at home. Archer et al. assumed that this result might help to explain different patterns of engagement with science. Depending on the social class the students grew up in, the experiments conducted were more or less formal or thus school science-related.

\section{Career interests in science-based technology jobs}

Early adolescence is a time of active vocational development when young people contemplate school and career paths, obtain part-time jobs, make decisions about which additional subjects to take, and narrow the field of possible career choices. In Switzerland almost three-quarters of the school graduates (grade 9) start an apprenticeship while approximately

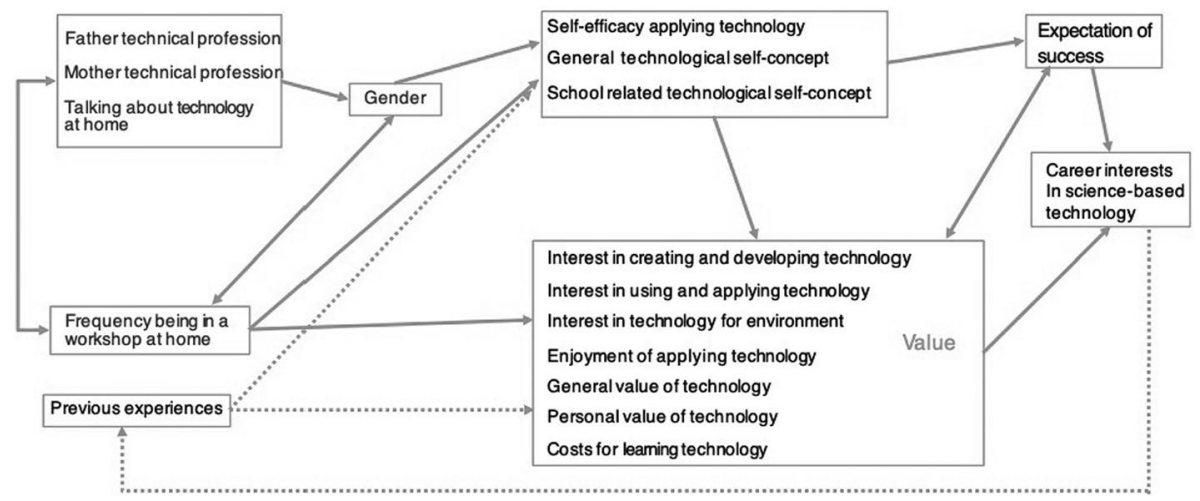

Fig. 1 Research model based on the expectancy-value model of Eccles and Wigfield (2002). Dotted lines are not analysed in this research 
one-quarter go on to higher secondary school (Wolter et al. 2018). Like many European countries, Switzerland has a dual apprenticeship system, which is vocational training combined with vocational school. As part of vocational training a vocational baccalaureate can be acquired that allows one to study at university. To illustrate the prevalence of this option, $60 \%$ of students enrolled at universities of applied science for technology and IT entered with a vocational baccalaureate.

Career intentions for STEM correlate with general interest in STEM subjects (Kudenko and Gras-Velázquez 2016). A STEM background, such as having a parent working in a STEM field, has a positive influence on the student's self-concept of their abilities and their career choice (Moakler and Kim 2014; Regan and DeWitt 2015; Wang and Degol 2013). However, parents' knowledge about STEM occupations generally seems to be limited with negative consequences for a career in the STEM field (Hall et al. 2011). Hall et al. (2011) conducted a study in a rural state of the US, which was especially concerned with the limited knowledge of science and math teachers and as well as job counsellors with respect to STEM careers, especially engineering.

Three key attitudes related to career choices include personal interests, self-efficacy expectations, and outcome expectations in a certain domain of behaviour (Betz and Hackett 2006). Students' attitudes towards science correlate with their outcomes in science and consequently predict STEM study selection (Guo et al. 2015). These findings suggest that interventions targeting the promotion of academic performance and STEM pathways should seek to enhance both self-concept of their abilities and intrinsic value, e.g., enjoyment. It needs to be mentioned that girls do not generally have lower academic scores in STEM (Stoet and Geary 2018). Capobianco et al. (2015), for example, obtained higher scores for girls doing engineering activities in almost all five grades in elementary school. The problem is that girls who are good in STEM subjects seem to do even better in language subjects (Stoet and Geary 2018). Based on expectancy-value theory persons pursue a career in those subjects in which they are most competent. Hence, girls opt for a profession in the humanities or social sciences.

Teaching projects that aim to raise students' interest and enjoyment of science and related technology activities appear to have the potential to spark later career interest (Mohd Shahali et al. 2017). Capobianco et al. (2015) investigated whether or not elementary school students' engagement in engineering design-based science learning activities had an effect on their engineering identity development. The results of their study suggest that when exposed to standards-based engineering learning activities, elementary school students demonstrate improved understanding of the work of an engineer, their own abilities to engage in science and math problem-solving, and their aspirations to become engineers. Hence, their self-concept for science and technology develops positively. Another possibility to alter students' ability self-concepts is utility value interventions, such as identifying personal utility value connections between students' lives and what they are learning in class. These have been found to be effective in triggering interest and promoting academic performance in STEM topics (Aeschlimann et al. 2016; Hulleman and Harackiewicz 2009).

\section{Out-of-school experiences}

Out-of-school experiences seem to enhance students' interest in the STEM field (Henriksen et al. 2015). However, visits to companies are not amongst the highest rated experiences. Students' participation in out-of-school activities, their gender as well as their middle school 
interest in science and mathematics all play a significant role in their university career interest in STEM (Dabney et al. 2012). Dabney et al. (2012) distinguish structured and unstructured out-of-school experiences. The first include museum visits and programmes, science groups, clubs, camps, and science and mathematics competitions. The second group includes a large number of activities that occur in an unstructured manner, without any sort of scaffolding other than individual pursuit of activities; these range from conversations or socializing, tinkering with objects, personal science hobbies, and reading nonfiction science and science fiction. Programmes aimed at students experiencing hands-on science experiments in industries are not very well known. Industry-school initiatives wherein students participate in real work situations produce authentic learning opportunities that enable school-to-work transitions (Watters et al. 2016). Levine and DiScenza (2018) designed, implemented, and evaluated a full-day outreach programme for high school girls that focused entirely on activities related to the sugar industry. The authors report positive career interest developments during the time of the project. Such factory visits are also helpful for expanding students' knowledge of professions. Australian secondary school students, for example, seem to have little idea of the range of workplace possibilities that a science degree offers (Rodrigues et al. 2007). They didn't realize that careers in science, engineering, and technology open up opportunities for areas such as communication, information management or planning and organizing. These skills are rated highly by students, but they do not attribute them to science jobs. Similarly, in a study carried out in Switzerland by Aeschlimann et al. (2016), more extensive information about STEM professions predicted STEM study choice.

\section{Research questions}

The basis of our research is the expectancy-value model of Wigfield and Eccles (2002). In an expectancy-value model career interests are explained by the student's expectation of success and by the student's values regarding a subject. We adapted the variables of the original model for science-based technology and related career interests (Fig. 1). In addition, relevant context variables such as gender, technical profession of father or mother, the prevalence of technology as a topic at home and being in a workshop at home were included (Becker and Maunsaiyat 2002). These variables have an influence on expectations and values.

The main question is the following: Is there a development in students' career interests in science-based technology professions over time?

This includes the following sub-questions:

1. Are there differences in the development of career interest between the intervention and control groups?

2. Which factors explain the development of career interest?

3. Are there differences in the relationship of the predicting factors between the intervention and control groups?

\section{Method}

\section{Design}

Our longitudinal research design was embedded within a bi-national STEM implementation project. The fully mixed concurrent equal status design (Schoonenboom and 
Johnson 2017) combines QUAN + QUAL student data. The mixed-methods data are used for reasons of triangulation and complementation in this paper. The Swiss-Austrian project started in 2016 and ended in 2018, lasting 2 years. The principal aim was to network industry and school and to motivate secondary school students regarding science-based technology topics and career aspirations. Some companies were interested in recruiting students as future apprentices. As part of the project, secondary school students in the region of St. Gallen $(\mathrm{CH})$ and Vorarlberg (AT) visited a local company with a STEM background and worked on STEM tasks related to the company's products. Each local industry-school part of the project was designed by teachers and industry partners according to their requirements. Hence, the duration, content and tasks differed for each industry-school partner. The majority of the students undertook one visit, some two and a few spend several afternoons in the company. For this study the three participating companies had the following background: Chainsaws, filter technologies, and springs. The teacher(s) prepared the factory visits and reflected with the students afterwards in class or school. This often included an in-class presentation of the jobs encountered or tasks completed as part of the visit. The accompanying development and research team from the teacher university helped to organize, provided pedagogical content knowledge (PCK) and arranged exchanges with preceding industry-school project partners. We also participated at local conferences and tried to bring in advise and experience.

\section{Participants}

The sample for this study consists of 213 Swiss secondary school students (grades 7-9) from 9 classes who took part in the 3 industry-school projects and 72 from 4 classes in 4 neighbouring schools as a control group. The age range lies between 12 and 17 years. The teachers for the control group and their classes were selected through personal contacts of teachers from the project group. As the control group teachers and classes are from neighbouring schools with the same characteristics, comparability is ensured. The mean age in the project group was 13 and in the control-group 14 years old; the majority of the students in the project group belonged to grade 7 and in the control group to grade 8 . In addition, we conducted group interviews in four schools from the project group, $\mathrm{N}=16$ students ( $4 \times 2$ female, 2 male). We asked the teachers to put together a group of four high and low achieving students of both sexes.

\section{Instruments}

The student questionnaire consists of items on students' attitudes towards science-based technology and of some variables related to the students' background, e.g., gender, father or mother's job, and importance of technology at home. Our items refer to the expectancy value model of achievement by Eccles and Wigfield (2002), see Fig. 1. Most of the items were adapted from literature; Items related to costs are adapted from Flake et al. (2015) and Kosovich et al. (2014), to interest and value from Güdel (2014) and PISA 2006 (Organisation for Economic Co-operation and Development (OECD) 2006a). Another four items asked for the students' future job wishes as in Riegle-Crumb et al. (2011). In the German language, the term technology relates solely to engineering and science-based technology but not to the use of computers. Therefore, we used the term technology without further clarification in our questionnaire. Among the scales are three that cover the expectancy dimension of the model (sample item in brackets): (1) Technology-related ability 
self-concept (although I show efforts, I have problems applying technology), (2) self-efficacy (I feel capable of exchanging a bulb), and (3) school-related technological ability selfconcept (I easily follow technology-related topics at school). Another seven scales form the value part of the model: (1) Interest in applying technology (I'm interested in repairing technical tools), (2) interest in creating technology (I'm interested in developing a technical tool in a team), (3) interest in environment-related technology (I'm interested in developing advertisements for environment-compatible tools), (4) fun in applying technology (I like to take technical tools apart), (5) general value (technology is important for society), (6) personal value of science-based technology (technology is very relevant to me), and finally (7) technology-related costs (to learn to understand how a technical tool functions is too much effort to me). Career interest was measured with four items (I can imagine working in the field of technology later). We utilized a 6-point Likert scale for the questionnaire items $(6=$ absolutely agree, $5=$ agree, $4=$ somewhat agree, $3=$ somewhat disagree, $2=$ disagree, and $1=$ absolutely disagree). We did not measure utility value as such, but items of the value scales 2 and 3 refer to how an activity fits into an individual's perceptions of the future. All items are summarized in scales with four or five items and checked for reliability (Cronbach Alpha > .70). In line with Eccles and Wigfield's model we included five context variables related to the student's cultural milieu and family background. These items ask for gender, whether father or mother have a technical profession, how often technology is a topic at home and how often the student spends time in a workshop at home.

The interview followed a structured guideline. By using the semi-structured design, we ensured that all students were confronted with the same key questions. After questions relating to technology and science at school, the students had to report about the factory visit, including what they had liked and disliked. Then, they were asked about their perceptions of technology and whether their interest in technology had increased. Finally, a section on each student's career choice followed, which explored their intentions at the moment and explanations for their choice, including whether they would consider an apprenticeship with the company that they visited.

\section{Analyses}

Statistical analyses (descriptive analysis, correlations) of the student data were conducted with SPSS. Confirmatory factor analysis (CFA) and structural equation models (SEM) to analyse the relationships of the expectation-value model were calculated with MPlus 8. To test whether the model was appropriate, model fit indices regarding the items were reviewed (Hu and Bentler 1999). Given that missing values were not due to the design of the study, we assumed that they occurred randomly and consequently applied the full information maximum likelihood (FIML) procedure as a model-based treatment of missing data (Enders 2010).

As a methodological framework for the analysis of the interview material we referred to qualitative content analysis (Mayring 2000). The coding process followed the structure of the guideline. Each question of the guideline referred to certain themes. Additional themes appeared when students began to talk about things connected to the research topic but not foreseen by the research team or not of central interest. Accordingly, codes were partly developed deductively as well as inductively, as part of the coding process. For the interview data we applied computer-assisted content analysis using the software MAXQDA 2018. Integration of the data sources occurred at the end of the separate analysis of each source. The aim was to compare and complement findings from each analysis (Bazeley 
2012). A special target of our data triangulation was to validate the empirical results from this research.

\section{Results}

\section{Quantitative analysis}

As a start, CFA was used to check whether the scales related to ability self-concept or value of technology would load on the two factors of expectancy and values (Fig. 1). The analysis showed that the scales had to be arranged differently. One factor comprises expectancy, costs and attainment values, while the other factor includes interest values e.g., enjoyment of the activity. This was presented in detail in another study (Smit et al. 2019) and will be addressed in the discussion section. We labelled the two factors "expectancy-value attitudes for science-based technology" and "attitudes for applying science-based technology". In a following step, measurement invariance over time was tested and scalar invariance was reached (Table 1, Fig. 2). If scalar invariance is reached, mean difference testing is allowed, and the same constructs are measured over time. Measurement invariance is evaluated using $\chi^{2}$-difference testing. Non-significance between two successive steps signifies that the two models are comparable. In Table 1 this is the case for the step from metric to scalar invariance. Because $\chi^{2}$ is sometimes not trustworthy a criterion of a -.01 change in CFI for nested models is commonly used in addition (Putnick and Bornstein 2016). Both steps-from configural to metric invariance and from metric to scalar invariance-are below this criterium, and therefore, the three models are regarded as equal.

Generally, the secondary school students' attitudes are slightly positive with rather high standard deviations (Table 2). Students' interest in a future job in a technology-related branch is rather low but there is again a high standard deviation. Approximately one-quarter of the students show high means $(\geq 5)$ indicating interest in a future technology-based career.

To determine whether our project had produced some effects over time we compared the summated mean values of both groups for each of the two factors. For the first factor (expectancy) $F$ tests showed no interaction between time and group, Wilks Lambda $=1.00, F(1,205)=.002, p=.96$, partial eta $^{2}=.00$. The second factor (applying) showed a significant small decline over time for the intervention group compared to the control group, Wilks Lambda $=.98, F(1,205)=4.47, p=.04$, partial eta ${ }^{2}=.02$. Career choice also declined slightly in the intervention group compared to the control group.

Table 1 Series of CFA models investigating measurement invariance between the two time points of expectancy and applying science-based technology attitudes

\begin{tabular}{llllllll}
\hline Parameters constrained to be equal & $\chi^{2}$ & $d f$ & CFI & TLI & RMSEA & $\Delta \chi^{2}$ & $\Delta$ CFI \\
\hline 1. Unconstrained (configural invariance) & 278.166 & 94 & .956 & .943 & .075 & - & - \\
2. Factor loadings (metric invariance) & 296.396 & 100 & .953 & .943 & .075 & $*_{s}$ & .003 \\
3. Intercepts (scalar invariance) & 305.672 & 106 & .952 & .945 & .073 & n.s. & .001 \\
\hline
\end{tabular}

CFA confirmatory factor analyses; CFI comparative fit index; TLI Tucker-Lewis index; RMSEA root mean square of approximation; model comparison with Chi squared test

*Sign., $p<.01$ 


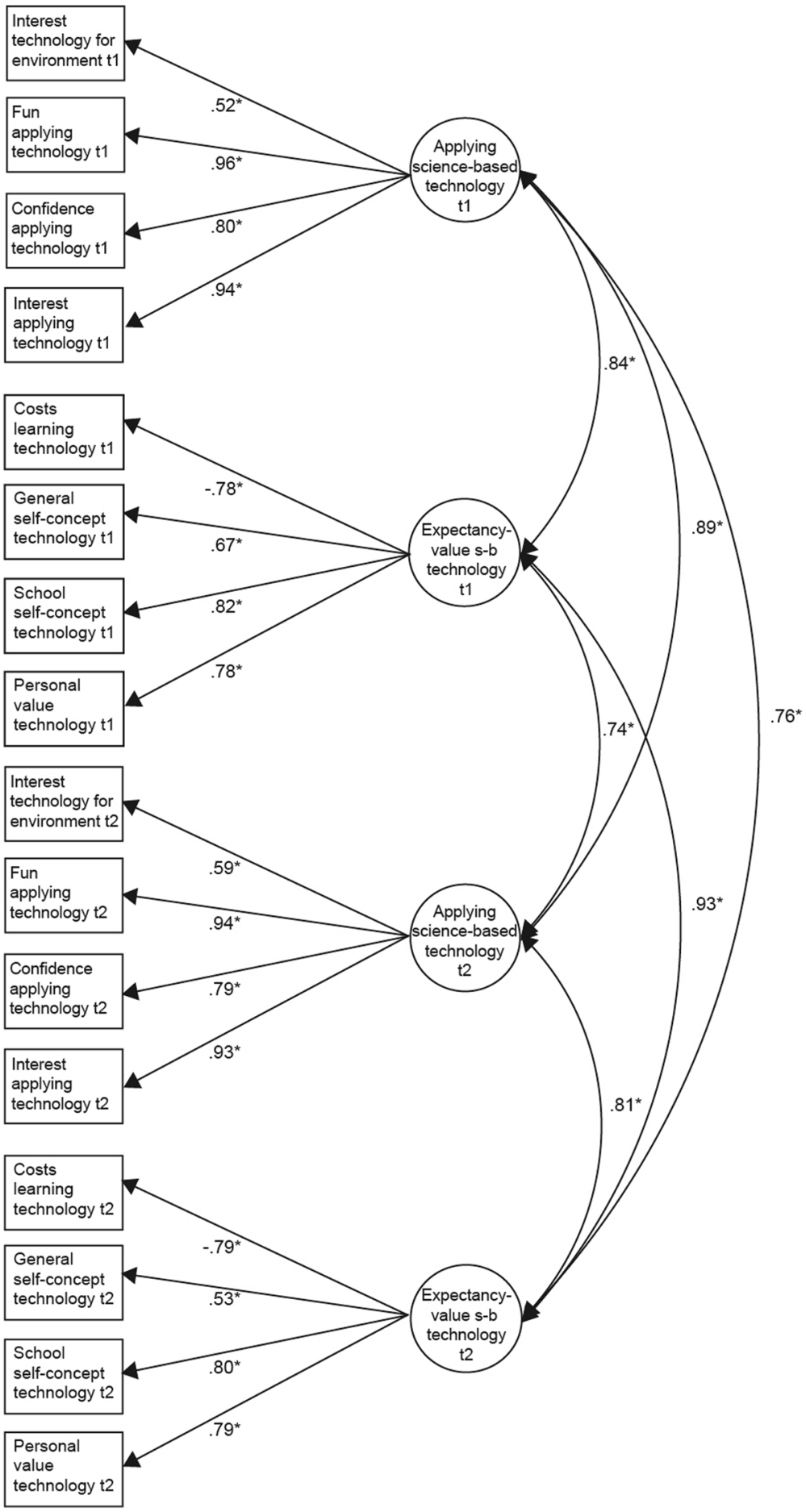

Fig. 2 Longitudinal CFA for development of expectancy-value and applying science-based technology attitudes. Note: $N=285$; *all paths $p<.05$, estimates are standardized 
Table 2 Means and standard deviations for expectancy, value and career choice engineering technology for pre- and postproject

\begin{tabular}{|c|c|c|c|c|}
\hline \multirow[t]{2}{*}{ Time period } & \multicolumn{2}{|c|}{$\begin{array}{l}\text { Intervention group } \\
(n=213)\end{array}$} & \multicolumn{2}{|c|}{$\begin{array}{l}\text { Control group } \\
(n=74)\end{array}$} \\
\hline & $M$ & $S D$ & $M$ & $S D$ \\
\hline Expectancy t1 & 3.65 & .46 & 3.69 & .55 \\
\hline Expectancy t 2 & 3.68 & .44 & 3.72 & .57 \\
\hline Applying t1 & 3.60 & 1.01 & 3.53 & 1.15 \\
\hline Applying t2 & 3.41 & 1.03 & 3.54 & 1.18 \\
\hline Career choice $\mathrm{t} 1$ & 3.18 & 1.09 & 3.61 & 1.67 \\
\hline Career choice $\mathrm{t} 2$ & 3.08 & 1.20 & 3.75 & 1.52 \\
\hline
\end{tabular}

All scales $1-6$, $(6=$ absolutely agree, $5=$ agree, $4=$ somewhat agree, $3=$ somewhat disagree, $2=$ disagree, and $1=$ absolutely disagree)

However, interaction between time and group was not significant, Wilks Lambda $=.98$, $F(1,205)=3.79, p=.05$, partial eta ${ }^{2}=.02$. For all three variables, the effect sizes are very small; hence, the project seems not to have had any effect on the development of the students' attitudes and career orientations. Based on the theoretical expectancy-value model it is also interesting to learn how the three variables interacted over time. Therefore, the relationship between the two factors over time as a mean to explain the development of STEM career choice was investigated. In an earlier study (Smit et al. 2019) a structural equation model (SEM) that predicted career choice in science-based technology was established for $\mathrm{t} 1$ only. This study showed that expectancy-value attitudes had a direct effect on career choice and an indirect effect via applying science-based technology attitudes. Based on this t1-model a longitudinal one-group model with parceled items was constructed. Cross-lagged paths were included in a similar way as in the models in Fig. 3. The fit values were good: $\chi^{2}=7.46, \mathrm{df}=4, p=.11, \mathrm{CFI}=.997, \mathrm{TLI}=.97, \mathrm{RMSEA}=.057$. Girls (Gender) generally had lower attitudes and career aspirations for science and engineering professions (Table 3). Father having a technical profession did not have an influence on students' attitudes or career choices (with one exception). Mother was not included in the model because that variable did not show any significance as a predictor. Age predicted career choice at $\mathrm{t} 1$ only and was not included either. Talking about techniques or participating in a workshop had a mixed positive effect on students' attitudes but not on their career choices.

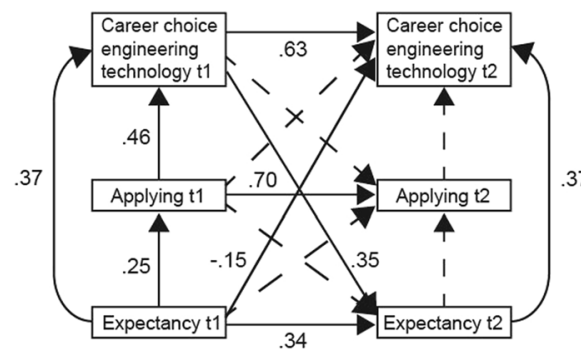

control group

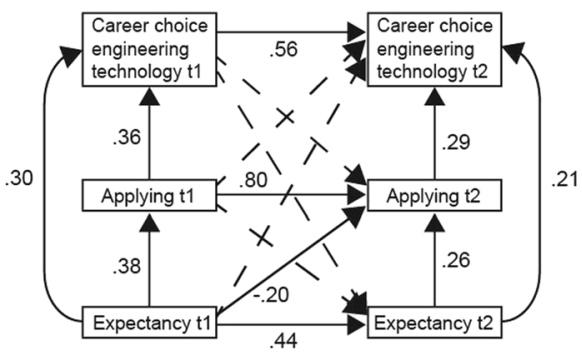

intervention group

Fig. 3 Two-group structural equation model for the development of secondary students'career choice for science-based technology and engineering professions. Note: $N=285$; *all solid lines are significant; $p<.05$, estimates are standardized 
Table 3 Regression coefficients of an SEM analysing students' career choice for science-based technology and engineering professions

\begin{tabular}{|c|c|c|c|c|c|c|c|c|c|c|c|c|}
\hline & \multicolumn{2}{|c|}{$\begin{array}{l}\text { Expectancy } \\
\text { t2 }\end{array}$} & \multicolumn{2}{|c|}{$\begin{array}{l}\text { Expectancy } \\
\text { t1 }\end{array}$} & \multicolumn{2}{|c|}{$\begin{array}{l}\text { Applying } \\
\text { t2 }\end{array}$} & \multicolumn{2}{|c|}{$\begin{array}{l}\text { Applying } \\
\text { t1 }\end{array}$} & \multicolumn{2}{|c|}{$\begin{array}{l}\text { Career } \\
\text { choice } \mathrm{t} 2\end{array}$} & \multicolumn{2}{|c|}{$\begin{array}{l}\text { Career } \\
\text { choice } \mathrm{t} 1\end{array}$} \\
\hline & B & SE & ß & SE & B & SE & $ß$ & SE & $\beta$ & $\mathrm{SE}$ & $\beta$ & SE \\
\hline Applying t1 & -.09 & .08 & - & - & $.75 *$ & .05 & - & - & -.07 & .07 & $.36^{*}$ & .06 \\
\hline Expectancy t1 & $.42 *$ & .07 & - & - & $-.14 *$ & .06 & $.38^{*}$ & .05 & -.05 & .05 & $.32 *$ & .05 \\
\hline Career choice $\mathrm{t} 1$ & $.18^{*}$ & .07 & - & - & -.03 & .06 & - & - & $.61^{*}$ & .05 & - & - \\
\hline Expectancy t 2 & - & - & - & - & $.19^{*}$ & .05 & - & - & $.26^{*}$ & .05 & - & - \\
\hline Applying t2 & - & - & - & - & - & - & - & - & $.24 *$ & .07 & - & - \\
\hline Gender & $-.20^{*}$ & .06 & $-.48 *$ & .05 & $-.13 *$ & .05 & $-.21 *$ & .05 & - & - & $-.21 *$ & .05 \\
\hline Father technical profession & .05 & .05 & .06 & .05 & .02 & .04 & $-.10^{*}$ & .04 & - & - & .09 & .04 \\
\hline Technique topic at home & $.15^{*}$ & .06 & $.13^{*}$ & .05 & .03 & .04 & $.14^{*}$ & .05 & - & - & .05 & .05 \\
\hline In workshop at home & .01 & .06 & $.11^{*}$ & .05 & $.95^{*}$ & .03 & $.26^{*}$ & .05 & - & - & -.07 & .05 \\
\hline$R^{2}$ & .50 & .05 & .32 & .05 & .72 & .03 & .49 & .04 & .74 & .03 & .56 & .04 \\
\hline
\end{tabular}

$N=285 ; *=p<.05, S E=$ Standard Error

Opting for a science-based technology career after the industry visit (t2) was predicted by career choice interest at $\mathrm{t} 1$ as well as students' expectancy and attitudes towards applying science-based technology at $\mathrm{t} 2$. There were also indirect effects on career choice $\mathrm{t} 2$ for both attitudes at $\mathrm{t} 1$ mediated by the attitudes at $\mathrm{t} 2$. These effects will be described in more detail below based on the two-group model.

To answer the question whether there are differences in the relationship of the predicting factors for career choice $\mathrm{t} 2$ between the intervention and the control group, a two-group structural equation model (SEM) was constructed (Fig. 3). Context variables like, e.g., gender, were included but are not shown in Fig. 3 for reasons of clarity. This model shows good fit indices: $\mathrm{CFI}=.997, \mathrm{TLI}=.968, \mathrm{RMSEA}=.059$.

Career choice appears to be relatively stable over the duration of the project, but students' attitudes experience an effect. The main difference between the two group models lies in the role of the application of technology for career choice. While in the intervention group, applying science-based technology activities at $\mathrm{t} 2$ and indirectly also at $\mathrm{t} 1$ predicts career choice, this factor is not relevant in the control group. One interesting path goes from expectancy at $\mathrm{t} 1$ via applying technology at $\mathrm{t} 2$ to career choice. Those students with low expectancy attitudes at $\mathrm{t} 1$ show high attitudes for applying technology at $\mathrm{t} 2$ and ultimately a higher interest in a technology career. In the control group career interest at $\mathrm{t} 2$ in technology and engineering professions depends on students' expectancy-value attitudes at $\mathrm{t} 1$ and $\mathrm{t} 2$ only. A similar model such as the one for the control group was utilized in an earlier investigation analysing $\mathrm{t} 1$ data only combined for both groups (Smit et al. 2019).

\section{Qualitative analysis}

Qualitative analysis helps to understand unanticipated outcomes and to evaluate processes in complex dynamic systems (Patton 2015). We could not detect but had expected, a positive effect of our project on career interest in the quantitative analysis. How can we explain this? Focusing on process involves looking at how something happens. What are the factors that the students experience? How are the activities in 
which they engage related to the self-concepts of their abilities? When do students become interested in a profession with an engineering company? Finally, what can we learn for the modification of an as yet unsuccessful programme?

By listening to the students' accounts of their experiences during the industry visits, positive and negative aspects emerged (Table 4). These aspects were, however, not all related to the experience of the visit in the narrow sense, two additional themes appeared. One was the company, its products, appearance, the people working there and the working conditions. The other one was the matching of the company to the career intentions of the student. Did they offer the sought-after profession and how did the available professions suit the students' expectations? There was also a time factor in connection to the career orientation. Did the visit take place at the right time of the students' career planning or was it perhaps too late for a consideration of the visited company? The visit itself, the third theme, was mostly described in favourable terms by the students. Either it was said that they gained new knowledge about the company and the professions or it was mentioned that they liked engaging in a particular aspect of the visit, for instance, producing a workpiece or operating a machine. Not all statements could be classified as either positive or negative. Some remarks were open or neutral, such as those shown in the column labelled 'process of career choice'. These statements provided information on the state of their career development processes.

Looking at the four themes allows for the formulation of a thesis regarding when a student might develop career interest in a job at the visited engineering industry workspace. First, the process of career choice must still be active. Then, the offered job must be in line with the students' career interests OR the presented job or activities must appeal to the student. Finally, the company must make an attractive impression on the students when they visit. This might sound simple, but when we look at the statements of the students, several things can go wrong during the visit or hinder interest in the company: It might be dirty, loud and hot; the information given may not satisfy the students or is delivered in an unfriendly way; the company is too far away, or the building is not new and impressive; finally, the timing can go wrong, meaning that a company in a similar branch with the same or different professions was already visited and an apprenticeship was perhaps agreed upon. All in all, it can be guessed from the analysis that if a class with 20 students visits a technology company there are probably just one or two of the class that might develop a career interest in technology. This estimation is supported by the yearly number of apprenticeship contracts in the field of technology and engineering.

\section{Discussion and conclusions}

Science-based technology is not yet a prominent topic in science lessons at secondary school in Switzerland. However, this is not untypical for other regions as well (Jones et al. 2013). Hence, up to now, students who have had no contact with technology at home, tinkering in a workshop for instance, did not have the chance to develop a positive self-concept of their engineering abilities during adolescence. As a consequence, many students miss not only procedural knowledge about the subject, but they generally have no idea what jobs in the engineering and technology sector look like. 


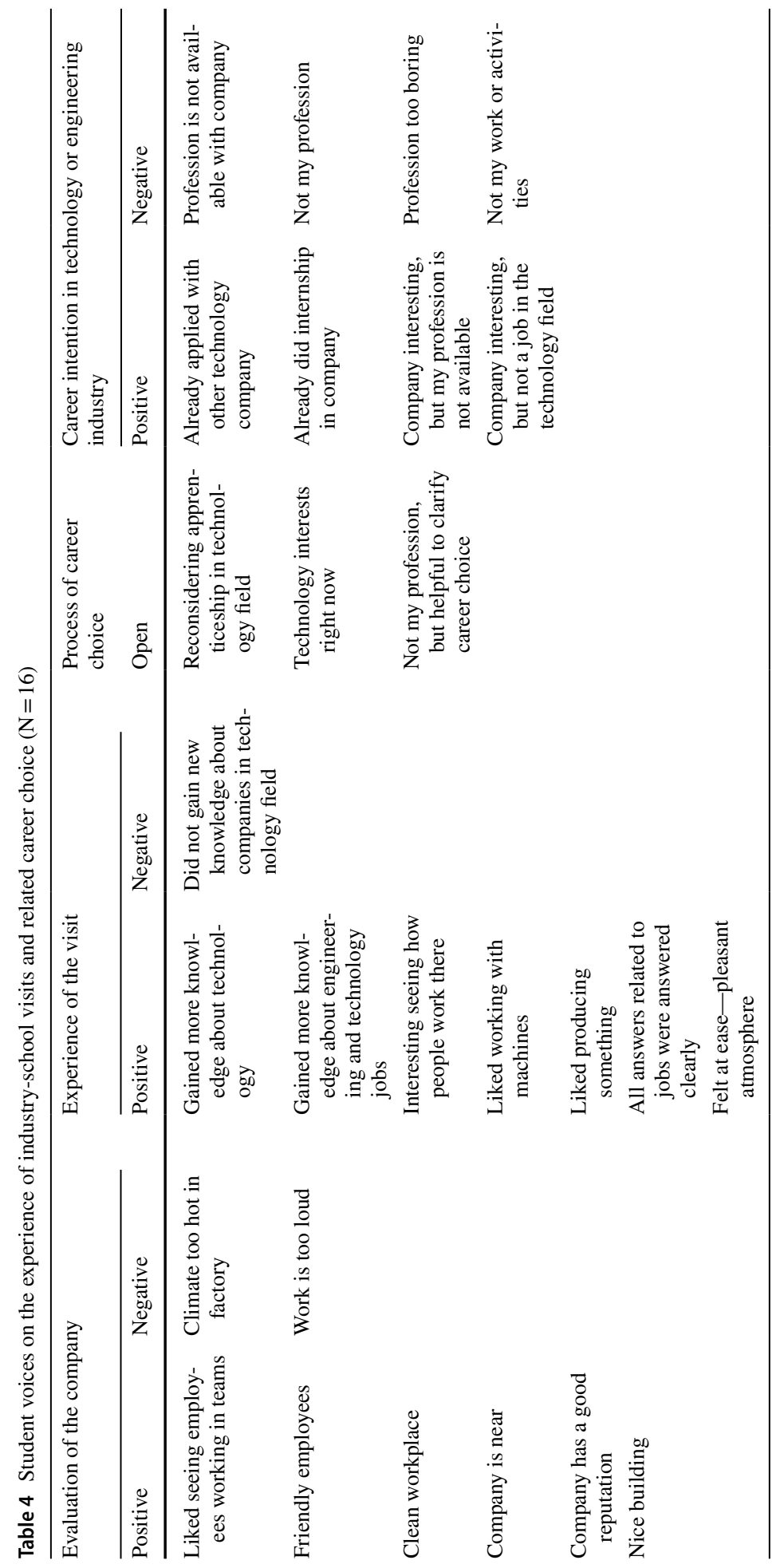




\section{Quantitative results}

In the following section the quantitative results are summed up. The first question relates to the effect of our project on the students' career interests. To answer this question, expectancy-value and application of technology attitudes were compared over time in two groups with no effect for expectancy-value and with a little negative effect for application attitudes. Unexpectedly, we found also no effects of the industry-school project on the development of the students' career interests. Based on the qualitative results this is discussed below in more detail. Second, we investigated which of the variables explained career interest. From the context variables, gender was the strongest predictor, having a negative effect on career choice. Girls possess lower aspirations for science related technology occupations than boys. The other context variables showed only indirect effects mediated by expectancy or applying technology. Overall, career choice proved to be of medium stability over time. The two main factors in our research model to explain career choice need to be explained for each group separately. With respect to the third question, interesting differences resulted between the two groups regarding the prediction of career choice over time. In the control group career choice is predicted solely by expectancy while in the intervention group expectancy and applying technology explain career interest over time. This result might indicate that the industry-school project leads to a change of students' perception of technology and engineering professions. In school, students experience science and probably also related technology often in form of a transmissive pedagogy, with decontextualized contents and unnecessary difficulty (Lyons 2006). After the industry-school visit applying science and technology has become a more salient feature of doing science and technology. As suggested by Ainley and Ainley (2011), the measurement of target variables in a SEM (Fig. 3) at both the general level (here ability self-concept for science-based technology) and the more specific level (here application of science-based technology) has given broader insight into the specific processes involved in student engagement with science-based technology as a prerequisite for career interest than either level of measurement alone. To be more precise, while students' ability self-concept (expectancy) and their personal value of technology seems to rest on their experience of science in school, enjoyment and interest for application of science appears to be encouraged during industry visits.

\section{Qualitative results}

The qualitative results indicate that the growth of career interest as part of an industryschool visit with accompanying preparation and reflection in school faces some obstacles. Is the visit at the right time of the students' career planning? Is the student open to considering a job in the technology field? Additionally, the image of the company is of importance as well as the working conditions. Finally, the activities must appeal to the student. As the students can choose among many apprenticeships, one of these factors can prevent students from continuing further inquiries about the job. Hence, the chance for a company to reach an applicant through an industry visit is not very high; however, very often in small to medium companies, there are not more than two apprenticeships available per year anyway. 


\section{Limits}

There are some limits of our study. First, the participant pool of secondary school students, and teachers came solely from one Swiss area in the northeast, which may limit generalizability. This is particularly the case if we think of the small number of classes in the control group. It is, however, difficult to find teachers willing to participate solely in a control group, as they can see no benefits for themselves. Therefore, it would be interesting to see whether other research in the field of science-based technology or engineering come to similar or different results. Second, in each school the project looked a little different with respect to preparation, visit, duration, tasks to be completed in the factory, and reflection. Hence, the results might be biased due to differences in local project realizations. On the other hand, it was important to transfer responsibility to the teachers and on-site industry partners in order to strengthen the long-term commitment and to foster interdisciplinary teamwork. This was also a recommendation of the research group who analysed the outcomes of a large industry-school visit project in Queensland, Australia (Watters et al. 2016).

Another limit was the coverage of the students' ability self-concept for technology, which was analysed solely based on the quantitative data. We conducted group interviews but did not ask individual students separately to explain if their self-beliefs might hinder them from applying for a job in the technology field. This could have brought to light additional knowledge with respect to the development of career interest in this field.

\section{Conclusion}

According to Archer et al. (2010) students' identities are responsible for career choices in secondary classes and are largely formed at the age of 14 . This is rather early for a young person who possesses only limited experience in the world of work. Our results indicate that factory visits combined with embedded tasks could be one way to overcome fixed ability self-concepts based on school science experiences. Even if career interest did not increase for the class as a whole, the insight into job-related science-based technology and working on practical tasks allowed the students to reconsider a career in the engineering industry towards the end of secondary school. Furthermore, it is always possible to switch after the first vocational qualification to another field of work. Women may perhaps feel more self-assured at a later age, enabling them to take up a career in a man-dominated field of work. Interestingly, many young people currently continue their education after a first diploma.

Therefore, such industry visits represent a unique opportunity for students to experience a previously undiscovered talent or interest for STEM professions-in the short or long term. The visits allow prospective school graduates insights into the working world. One of the advantages of company visits is that these activities give future apprentices the opportunity to meet older apprentices and professionals who are in a position to serve as attractive role models (Henriksen et al. 2015). Additionally, it is important for young women to see and talk to female employees in technology companies. Another result is the importance given to educating students about the career opportunities offered by science (Tytler and Osborne 2012). After all, students cannot aspire to that which they have never seen. These activities need to be implemented by teachers and job counsellors. Industry-school projects are 
occasions where teachers can acquire knowledge of the job opportunities or skills demanded for today's workforce (Harpole et al. 2010). Furthermore, it is important to observe whether the schools are able to maintain cooperative relationships with local industry. Polesel et al. (2017) describe this as posing challenges for the schools. There is, for instance, difficulty in adapting school structures to build effective partnerships. Students who participate in work placements might miss regular scheduled classes or have to use their spare time, which was also the case for some small additional projects in our project schools.

Finally, it should be considered for further research that because of the specific orientation of technology towards application, more studies are needed that explore differences between science and science-based technology attitudes and knowledge and how they interact in developing career interest in technology professions.

Acknowledgements This project was supported by the Interreg IV, Regio lake of Constance (Project No. $\mathrm{ABH} 005)$.

Open Access This article is distributed under the terms of the Creative Commons Attribution 4.0 International License (http://creativecommons.org/licenses/by/4.0/), which permits unrestricted use, distribution, and reproduction in any medium, provided you give appropriate credit to the original author(s) and the source, provide a link to the Creative Commons license, and indicate if changes were made.

\section{References}

Aeschlimann, B., Herzog, W., \& Makarova, E. (2016). How to foster students' motivation in mathematics and science classes and promote students' STEM career choice. A study in Swiss high schools. International Journal of Educational Research, 79, 31-41. https://doi.org/10.1016/j.ijer.2016.06.004.

Ainley, M., \& Ainley, J. (2011). Student engagement with science in early adolescence: The contribution of enjoyment to students' continuing interest in learning about science. Contemporary Educational Psychology, 36(1), 4-12. https://doi.org/10.1016/j.cedpsych.2010.08.001.

Archer, L., DeWitt, J., Osborne, J., Dillon, J., Willis, B., \& Wong, B. (2010). "Doing” science versus "being" a scientist: Examining 10/11-year-old schoolchildren's constructions of science through the lens of identity. Science Education, 94(4), 617-639.

Bazeley, P. (2012). Integrative analysis strategies for mixed data sources. American Behavioral Scientist, 56(6), 814-828. https://doi.org/10.1177/0002764211426330.

Becker, F. S. (2010). Why don't young people want to become engineers? Rational reasons for disappointing decisions. European Journal of Engineering Education, 35(4), 349-366. https://doi.org/10.1080/03043 797.2010.489941.

Becker, K. H., \& Maunsaiyat, S. (2002). Thai students' attitudes and concepts of technology. Journal of Technology Education, 13(2), 6-20.

Betz, N. E., \& Hackett, G. (2006). Career self-efficacy theory: Back to the future. Journal of career assessment, 14(1), 3-11. https://doi.org/10.1177/1069072705281347.

Bybee, R. W. (2000). Achieving technological literacy: A national imperative. Technology Teacher, 60(1), 23.

Bybee, R. W., McCrae, B., \& Laurie, R. (2009). PISA 2006: An assessment of scientific literacy. Journal of Research in Science Teaching, 46(8), 865-883. https://doi.org/10.1002/tea.20333.

Capobianco, B. M., Yu, J. H., \& French, B. F. (2015). Effects of engineering design-based science on elementary school science students' engineering identity development across gender and grade. Research in Science Education, 45(2), 275-292. https://doi.org/10.1007/s11165-014-9422-1.

Dabney, K. P., Tai, R. H., Almarode, J. T., Miller-Friedmann, J. L., Sonnert, G., Sadler, P. M., et al. (2012). Out-of-school time science activities and their association with career interest in STEM. International Journal of Science Education, Part B, 2(1), 63-79. https://doi.org/10.1080/21548455.2011.629455.

De Vries, M. (2001). The history of industrial research laboratories as a resource for teaching about sciencetechnology relationships. Research in Science Education, 31(1), 15-28.

Eccles, J. S. (2009). Who am I and what am I going to do with my life? Personal and collective identities as motivators of action. Educational Psychologist, 44(2), 78-89. https://doi.org/10.1080/0046152090 2832368 . 
Eccles, J. S. (2011). Gendered educational and occupational choices: Applying the Eccles et al. model of achievement-related choices. International Journal of Behavioral Development, 35(3), 195-201. https ://doi.org/10.1177/0165025411398185.

Eccles, J. S., Barber, B., \& Jozefowicz, D. (1999). Linking gender to educational, occupational, and recreational choices: Applying the Eccles et al. model of achievement-related choices. In W. B. Swann, J. H. Langlois, \& L. A. Gilbert (Eds.), Sexism and stereotypes in modern society: The gender science of Janet Taylor Spence (pp. 153-192). Washington: American Psychological Association.

Eccles, J. S., \& Wigfield, A. (2002). Motivational beliefs, values, and goals. Annual Review of Psychology, 53(1), 109-132.

Enders, C. K. (2010). Applied missing data analysis. New York: Guildford.

Fensham, P. J. (1988). Approaches to the teaching of STS in science education. International Journal of Science Education, 10(4), 346-356.

Flake, J. K., Barron, K. E., Hulleman, C., McCoach, B. D., \& Welsh, M. E. (2015). Measuring cost: The forgotten component of expectancy-value theory. Contemporary Educational Psychology, 41, 232-244.

Goreth, S., Geißel, B., \& Rehm, M. (2015). Erfassung fachdidaktischer Lehrkompetenz im technikbezogenen Unterricht der Sekundarstufe 1. Instrumentenkonstruktion und erste Befunde. Journal of Technical Education (JOTED), 3(1), 13-38

Güdel, K. (2014). Technikaffinität von Mädchen und Jungen der Sekundarstufe I. (Doctorate), University of Geneva, Geneva.

Guo, J., Parker, P. D., Marsh, H. W., \& Morin, A. J. S. (2015). Achievement, motivation, and educational choices: A longitudinal study of expectancy and value using a multiplicative perspective. Developmental Psychology, 51(8), 1163-1176.

Hall, C., Dickerson, J., Batts, D., Kauffmann, P., \& Bosse, M. (2011). Are we missing opportunities to encourage interest in STEM fields? Journal of Technology Education, 23(1), 32-46.

Harpole, S. H., Kerley, L. H., Silvernail, D. L., Kinard, F., \& Brooks, P. (2010). SCIENCE on the SHIPYARD: Bridging the gap between industry and the classroom. The Science Teacher, 77(4), 48-52.

Henriksen, E. K., Dillon, J., \& Ryder, J. (2015a). Understanding student participation and choice in science and technology education. Dordrecht: Springer.

Henriksen, E. K., Jensen, F., \& Sjaastad, J. (2015b). The role of out-of-school experiences and targeted recruitment efforts in norwegian science and technology students' educational choice. International Journal of Science Education, Part B, 5(3), 203-222. https://doi.org/10.1080/21548455.2014.900585.

Hu, L.-T., \& Bentler, P. M. (1999). Cutoff criteria for fit indexes in covariance structure analysis: Conventional criteria versus new alternatives. Structural Equation Modeling: A Multidisciplinary Journal, 6(1), 1-55.

Hulleman, C. S., \& Harackiewicz, J. M. (2009). Promoting interest and performance in high school science classes. Science, 326(5958), 1410-1412. https://doi.org/10.1126/science.1177067.

Jones, A. (2012). Technology in science education: Context, contestation, and connection. In B. J. Fraser, K. Tobin, \& C. J. McRobbie (Eds.), Second international handbook of science education (pp. 811-821). Dordrecht: Springer.

Jones, A., Buntting, C., \& de Vries, M. J. (2013). The developing field of technology education: A review to look forward. International Journal of Technology and Design Education, 23(2), 191-212. https://doi. org/10.1007/s10798-011-9174-4.

Kosovich, J. J., Hulleman, C. S., Barron, K. E., \& Getty, S. (2014). A practical measure of student motivation establishing validity evidence for the expectancy-value-cost scale in middle school. The Journal of Early Adolescence, 35(5-6), 790-816.

Kudenko, I., \& Gras-Velázquez, À. (2016). The future of european STEM workforce: What secondary school pupils of europe think about STEM industry and careers. In N. Papadouris, A. Hadjigeorgiou, \& C. Constantinou (Eds.), Insights from research in science teaching and learning. Contributions from science education research (Vol. 2, pp. 223-226). Cham: Springer.

Laine, E., Veermans, M., Lahti, A., \& Veermans, K. (2017). Generation of student interest in an inquiry-based mobile learning environment. Frontline Learning Research, 5(4), 42-60.

Levine, M., \& DiScenza, D. J. (2018). Sweet, sweet science: Addressing the gender gap in STEM disciplines through a one-day high school program in sugar chemistry. Journal of Chemical Education, 95(8), 13161322. https://doi.org/10.1021/acs.jchemed.7b00900.

Levine, M., Serio, N., Radaram, B., Chaudhuri, S., \& Talbert, W. (2015). Addressing the STEM gender gap by designing and implementing an educational outreach chemistry camp for middle school girls. Journal of Chemical Education, 92(10), 1639-1644. https://doi.org/10.1021/ed500945g.

Lyons, T. (2006). Different countries, same science classes: Students' experiences of school science in their own words. International Journal of Science Education, 28(6), 591-613. https://doi.org/10.1080/0950069050 0339621. 
Masson, A.-L., Klop, T., \& Osseweijer, P. (2016). An analysis of the impact of student-scientist interaction in a technology design activity, using the expectancy-value model of achievement related choice. International Journal of Technology Design Education, 26(1), 81-104. https://doi.org/10.1007/s10798-014-9296-6.

Mayring, P. (2000). Qualitative content analysis. Forum: Qualitative Social Research, 1(2), 159-176.

Moakler, M. W., \& Kim, M. M. (2014). College major choice in STEM: Revisiting confidence and demographic factors. The Career Development Quarterly, 62(2), 128-142.

Mohd Shahali, E. H., Halim, L., Rasul, M. S., Osman, K., \& Zulkifeli, M. A. (2017). STEM Learning through engineering design: Impact on middle secondary students' interest towards STEM. Eurasia Journal of Mathematics, Science and Technology Education, 13(5), 1189-1211. https://doi.org/10.12973/euras ia.2017.00667a.

NGSS Lead States. (2013). Next generation science standards: For states, by states. Washington, DC: The National Academies Press.

Organisation for Economic Co-operation and Development (OECD). (2006a). Assessing scientific, reading and mathematical literacy. A framework for PISA 2006. Paris: OECD Publishing.

Organisation for Economic Co-operation and Development (OECD). (2006b). Evolution of student interest in science and technology studies. Paris: Global Science Forum.

Patton, M. Q. (2015). Qualitative research \& evaluation methods. Thousand Oaks: Sage.

Polesel, J., Klatt, M., Blake, D., \& Starr, K. (2017). Understanding the nature of school partnerships with business in delivery of vocational programmes in schools in Australia. Journal of Education and Work, 30(3), 283-298. https://doi.org/10.1080/13639080.2016.1165344.

Putnick, D. L., \& Bornstein, M. H. (2016). Measurement invariance conventions and reporting: The state of the art and future directions for psychological research. Developmental Review, 41, 71-90. https://doi. org/10.1016/j.dr.2016.06.004.

Regan, E., \& DeWitt, J. (2015). Attitudes, interest and factors influencing STEM enrolment behaviour: An overview of relevant literature. In E. K. Henriksen, J. Dillon, \& J. Ryder (Eds.), Understanding student participation and choice in science and technology education (pp. 63-88). Dordrecht: Springer, Netherlands.

Riegle-Crumb, C., Moore, C., \& Ramos-Wada, A. (2011). Who wants to have a career in science or math? Exploring adolescents' future aspirations by gender and race/ethnicity. Science Education, 95(3), 458-476.

Rodrigues, S., Tytler, R., Darby, L., Hubber, P., Symington, D., \& Edwards, J. (2007). The usefulness of a science degree: The "lost voices" of science trained professionals. International Journal of Science Education, 29(11), 1411-1433.

Sasson, I. (2018). Participation in research apprenticeship program: Issues related to career choice in STEM. International Journal of Science Mathematics Education Research Journal. https://doi.org/10.1007/s1076 3-017-9873-8.

Schoonenboom, J., \& Johnson, R. B. (2017). How to construct a mixed methods research design. KZfSS Kölner Zeitschrift für Soziologie und Sozialpsychologie, 69(2), 107-131. https://doi.org/10.1007/s1157 7-017-0454-1.

Simpkins, S. D., Davis-Kean, P. E., \& Eccles, J. S. (2006). Math and science motivation: A longitudinal examination of the links between choices and beliefs. Developmental Psychology, 42(1), 70.

Smit, R., Robin, N., \& De Toffol, C. (2019). Explaining secondary students' career intentions for technology and engineering jobs using an expectancy-value model (Submitted).

Stoet, G., \& Geary, D. C. (2018). The gender-equality paradox in science, technology, engineering, and mathematics education. Psychological Science, 29(4), 581-593. https://doi.org/10.1177/0956797617741719.

Tytler, R., \& Osborne, J. (2012). Student attitudes and aspirations towards science. In B. J. Fraser, K. Tobin, \& C. J. McRobbie (Eds.), Second international handbook of science education (pp. 597-625). Dordrecht: Springer.

Wang, M.-T., \& Degol, J. (2013). Motivational pathways to STEM career choices: Using expectancy-value perspective to understand individual and gender differences in STEM fields. Developmental Review, 33(4), 304-340. https://doi.org/10.1016/j.dr.2013.1008.1001.

Watters, J. J., Pillay, H., \& Flynn, M. (2016). Industry-school partnerships: A strategy to enhance education and training opportunities (064695749X). Retrieved from Brisbane.

Wigfield, A., \& Eccles, J. S. (2002). Development of achievement motivation. San Diego: Academic Press.

Wolter, S. C., Cattaneo, M. A., Denzler, S., Diem, A., Hof, S., Meier, R., \& Oggenfuss, C. (2018). Swiss education report 2018. Retrieved from Aarau.

Xie, Y., \& Achen, A. (2009). Science on the decline? Educational outcomes of three cohorts of young Americans. Population Studies Center Research Report, 09-684.

Publisher's Note Springer Nature remains neutral with regard to jurisdictional claims in published maps and institutional affiliations. 